\title{
Cladistic Analysis of Genus Amphidromus (Gastropods: Camaenidae) from Java, Indonesia: A Preliminary Study
}

\section{Felicia Zahida}

Faculty of Biology, Atma Jaya Yogyakarta University, Yogyakarta 55281, Indonesia

E-mail:feliciazda@mail.uajy.ac.id

\begin{abstract}
Abstrak
Karakter morfologi 8 spesies yang merupakan koleksi dari Museum Zoologi Bogor (satu spesies merupakan record koleksi baru berasal dari Taman Nasional Gunung Harimun) genus Amphidromus telah dianalisa Cladistik. Koleksi Museum ini Amphidromus banksi, A. furcillatus, A. filozonatus, A. heerianus, A. inversus, A. javanicus, dan A. palaceus dimana koleksi terbarunya adalah A. alticola.

Key words: Analisis Cladistik, Amphidromus banksi, A. furcillatus, A. filozonatus, A. heerianus, A. inversus, A. javanicus, A. palaceus, A. alticola, Jawa.
\end{abstract}

Diterima: 17 Oktober 2002, disetujui 10 Desember 2002

\section{Introduction}

The genus Amphidromus is one of the most interesting land snails in the tropical area, having a brightly colored shell and living on tree. The genus is a arboreal pulmonate land snails belonging to the family Camaenidae (Jutting, 1950, Laidlaw and Solem, 1961). According to Laidlaw and Solem (1961) Amphidromus can be found throughout Myanmar, Malaysia, Thailand, Laos, Cambodia, Vietnam, Southern part of Philippines and Indonesia. Fulton (1896 in Laidlaw and Solem, 1961) organized 142 variety into 64 species. Pilsbry's publication has increased the number of species to 81 (1900 in Laidlaw and Solem, 1961), while Laidlaw and Solem recognized only 74 species.

According to Jutting (1950) there are 9 species of Amphidromus in Java. These are $A$. alticola, A. perversus, A. winteri, A. javanicus, A. palaceus, A. heerianus, A. furcillatus, A. porcellanus, and A. filozonatus. Neither $A$. winteri, A. perversus nor A. porcellanus used in this analysis, on the other hand A. banksi and A. inversus were used. This study aims to hypothesize the sister group hierarchy and express the results in terms of branching diagrams called cladogram.

\section{Materials and Methods}

Materials

Eight species, three specimen repestictively, of Amphidromus were used in this study (Appendix 1 and 2). One of the species is new record of Amphidromus alticola gathered from Gunung Halimun National Park, West Java, while the rest are the old collection of Museum Zoology Bogor.

\section{Methods}

Morphological characters was developed from the key identification to species of Amphidromus (Jutting, 1950) with several additional morphometric characters selected from Zahida (1999). A number of 20 morphological characters appears in shells were used. Those are: (a) shape of shell $(0=$ high conical, $1=$ turreted), (b) striae of shell $(0=$ vertical, $1=$ spiral $),(c)$ ribs of shell $(0=$ with vertical fold/ribs, $1=$ without vertical fold), (d) transparency of shell $(0=$ transparent, $1=$ little transparent), (e) shape of umbilicus $(0=$ closed, $1=$ narrow slit, $2=$ perforate $),(f)$ shape of aperture $(0=$ oblique, $1=$ oval, $2=$ lunar $),(\mathrm{g})$ side of columellar $(0=$ with longitudinal fold, 1 = without longitudinal fold $)$, (h) size of shell $(0=$ large, broad, $1=$ 
smaller, more slender, (i) shells marking on growth-arrest $(0=$ present, $1=$ without $),(j)$ reflection of peristome $(0=$ little reflected, $1=$ reflected, $2=$ expanded, $(\mathrm{k})$ length of last whorl $(0=$ more than half total length, $1=$ half of the total length, (l) vertical color marking $(0=$ forked/bifurcate at their top, $1=$ not bifurcate, (m) basic color $(0=$ cream, $1=$ yellow, $2=$ white), (n) number of whorl $(0=5,1=6$, and $2=7$ ), (o) length of shell, (p) width of shell, (q) length of aperture, (r) width of aperture, (s) spire height, and (t) peristome thickness.

Characters (a) to (n) can be categorized as qualitative character while character (o) to (t) as quantitative character. Outgroup of this study using three specimen of species Pseudopartula galericulum. Both of Amphidromus and Pseudopartula are belong to family Pleurodontidae (Jutting, 1950) or Camaenidae (Burch, 1962). Computerized Cladistic analysis was performed using PAUP version 4.0 on IBM PC.

\section{Limitation of the study}

The time constrain in this study became the main problem, which limit the probability to get and develop the hypothetical sister group hierarchy and express the better results in terms of branching diagrams.

\section{Results and Discussion}

\section{Selection of Characters and Taxa}

Qualitative characters used in this study has been developed from Jutting's key identification to the species of genus Amphidromus (1950), while quantitative characters used in this study based on the previous study on morphometric characters of Pomacea spp (Zahida, 1999). Since the operation of Cladistic analysis are strongly influence by the selection and resolution of characters and taxa, the use of characters developed from Jutting will hopefully help to resolve the cladogram. The taxa of choice is genus Amphidromus because one live species of A. alticola has been found from Cikaniki, Gunung Halimun National Park during the fieldwork training and the availability of specimen of the other species in the museum to support this study.

\section{Coding of Characters}

The data set is formed from characters scored as discrete codes in column and taxa in rows. The qualitative data has been scored as stated in methods above without much difficulty. But, since this study was using 8 species from one genus, the similarities among them are many than their dissimilarity. Further, the developed characters were drawn from the key identification to species Amphidromus in Java by Jutting. In fact three out of nine species used in that key identification were not available in the museum (those are $A$. winteri, A. perversus, and A. porcellanus) and has been replaced by two other species i.e. A. banksi and A. inversus. As a consequence seven (7) of the characters have the same results and have to be excluded. Some of the excluded characters are: (a) shape of shell in which all are high conical, (b) striae of shell in which all of them are striated vertical, (c) ribs of shell in which all of them are without ribs, (d) transparency of shell, in which all of the species are little transparent, (e) shape of aperture in which all of them are oblique, (f) side of columellar in which all of them are without columellar fold, and (g) shells marking on growth-arrest in which all of them are without growth-arrest.

On the other hand, the quantitative data need to be developed further so that the data can be scored as discrete codes. To ease the problem the numerical data then were developed into ratio data such as width to length of shell ratio, width to length of aperture ratio, and spire height to length of shell ratio etc. Then scoring was done by plotting the data in the graph. The purpose of this process is to develop a gap among character of each species so that the discrete code can be achieved. In fact many of the data were continuous data in which the character of one species was overlapping with the character of other species. In fact there are many methods proposed to build a gap, i.e. simple gap coding, segment coding, divergence coding, range coding and gap-weighing (Kitching et al. 1998). According to Kitching et al. 1998, the problem are remain because in reality there were a sliding scale from widely overlapping characters to widely disjunct characters that 
have discrete gaps between them. These results gave a difficulty on scoring because those of the sliding scale have a different degree of overlap so that in the end all of those numerical characters were excluded.

\section{Determination of Cladogram}

The data matrix remains for the first trial was 27 taxa and 7 characters. Total number of rearrangements tried in heuristic search was $8,607,074$ and number of trees retained 1230, while score of best tree were 21 . The strict consensus of 1230 trees developed outgroup outside from the ingroup. For the ingroup, the resolving clade was not so good and shows many sisters group. Some specimen has close relationship such as A. furcillatus (specimen 10,11 and 12); A. A. heerianus (specimen 16,17 and 18); and A. javanicus (specimen 22 to 23), while the rest was sister group. The bootstrap with 100 replicates shows that the genus Amphidromus was supported by $83 \%$ of characters, A. furcilatus (specimen 10,11, and 12) supported by $74 \%$ of characters while $A$. heerianus (specimen 16, 17, and 18) supported by $56 \%$, and finally A. javanicus (specimen 22 and 23 ) by $51 \%$ of the characters (Figure 1 ).

One of the cladogram obtained was observed (Figure 2). There are some groups of very close relationship such as species $A$. filozonatus (specimen. 13, 14, and 15); $A$. furcilatus (specimen 10 and 11); A. javanicus (specimen 22 and 23); and A. heerianus (specimen 16, 17, and 18).

There is no resolution found for both of A. inversus (specimen 19, and 20), A. palaceus (specimen 25) and both specimen of $A$. javanicus (specimen 22 and 23), and they are called a polytomy group. This polytomy group has a sister group of A. palaceus (specimen 27). Third specimen of $A$. furcilatus (specimen 12) was grouped as sister group of $A$ furcilatus (specimen 10 and 11). Probably the latter is because of the reflection of the peristome, which is quite wide compared to the rest. No resolution was also found for species $A$. alticola (specimen 4, 5, and 6) in which this group became a sister group of $A$. filozonatus (specimen 13, 14, and 15) and species $A$. palaceus (specimen 26 ).
In the higher hierarchy, the clade shows that $A$. banksi is a sister group for group of $A$. alticola, A. filozonatus and A. palaceus. Further $A$. banksi also has a sister with $A$ furcilatus $A$. inversus, and $A$. javanicus, It seems that the A. heerianus phylogenic was separated earlier by the clade compared to the other species.

A. alticola, and $A$. banksi have no root. It means that those clades have not enough supporting characters to build a monophyletic group. A. inversus, A. javanicus, and A. palaceus (specimen 1) build a polytomous group, with the sister group of A. palaceus (specimen 3).

The second trial was made after evaluated the previous cladogram. Second opinion from the expert was also gathered for the coding process to avoid subjectivity of coding for some state by researcher. The result of the first tree shows that $P$. galericulum as a control was grouped outside the main clade. The cladogram presented in Figure 3 act as an example of a hundred (100) tree generated using matrix data set of 27 taxa and 8 characters . One additional character has been added up which is roughness of striae $(0=$ rough, 1 = fine). As one example of a hundred possibility it can not explain very much, and this cladogram act as a hypothetical phylogenetic tree.

The hierarchical sister group of the species can be described from the species that separated earlier to the latest (Figure 3). A. heerianus was separated earlier, and this species act as a sister group to the rest of species Amphidromus. A. banksi has no root when they grouped with others. In this case it means that there is no discriminate character for this species to others. Eight characters used do not good enough to build a good cladogram. As a comparison we can see A. alticola which has a root and act as a sister group for $A$ banksi and other, and formulate a polytomy group (compose of A. furcillatus, A. filozonatus, A. inversus, A. palaceus and A. javanicus). Among them A. palaceus was separated earlier then followed by $A$. filozonatus and $A$. javanicus, both of the latter were in different clades. The latest specimens separated were $A$. furcillatus and $A$. inversus. 
There is a complicated result for species A. palaceus grouping (See Figure 3), where each specimen was separated into different group. First specimen grouped together with $A$. inversus, second specimen act a sister group of A. furcillatus and A. filozonatus, and the third specimen act as a sister group for A. furcillatus, A. filozonatus, A. inversus, and A. javanicus. Secondly, the third specimen of A. inversus was act as a sister group of almost the rest of the species except $A$. heerianus. Those of the complicated results can be explained by using the consensus tree.

Figure 4 can be used to explain the cladogram results generated by the program. This consensus tree act like an average of those 100 cladogram results. In fact this tree is derived by combining only those components that appear in all member of a set of fundamental cladogram (Kitching et al., 1998). Hierarchical sister group of this tree is quite simple compare to the example tree above. A. heerianus was separated earlier then followed by specimen 3 of $A$. inversus, Many species act as a sister group of the others. Those are $A$. alticola, A. banksi, A. inversus (specimen 1 \& 2), A. javanicus, and A. palaceus. Then A. filozonatus was act as a sister group of $A$. furcillatus. Apparently this consensus tree almost shows no complicated branching clades. Observed unrooted clade shows that the number of character used in this study was not enough.

Several results can be showed in this study after first and second trial are:

1. A stable monophyletic group has been developed i.e. A. heerianus, A. furcillatus, $A$. alticola and $A$. inversus.

2. Unrooted clades has been developed i.e. A. banksi and A. filozonatus. It means that the character needed to develop synapomorphy was not enough.

3. There are some improvement of the confusing cladogram result, from 3 species in first trial (i.e. A. javanicus, A. inversus, and $A$. palaceus) to only one species in the second trial (A. palaceus).

4. A. heerianus is certainly separated earlier in every cladogram built.

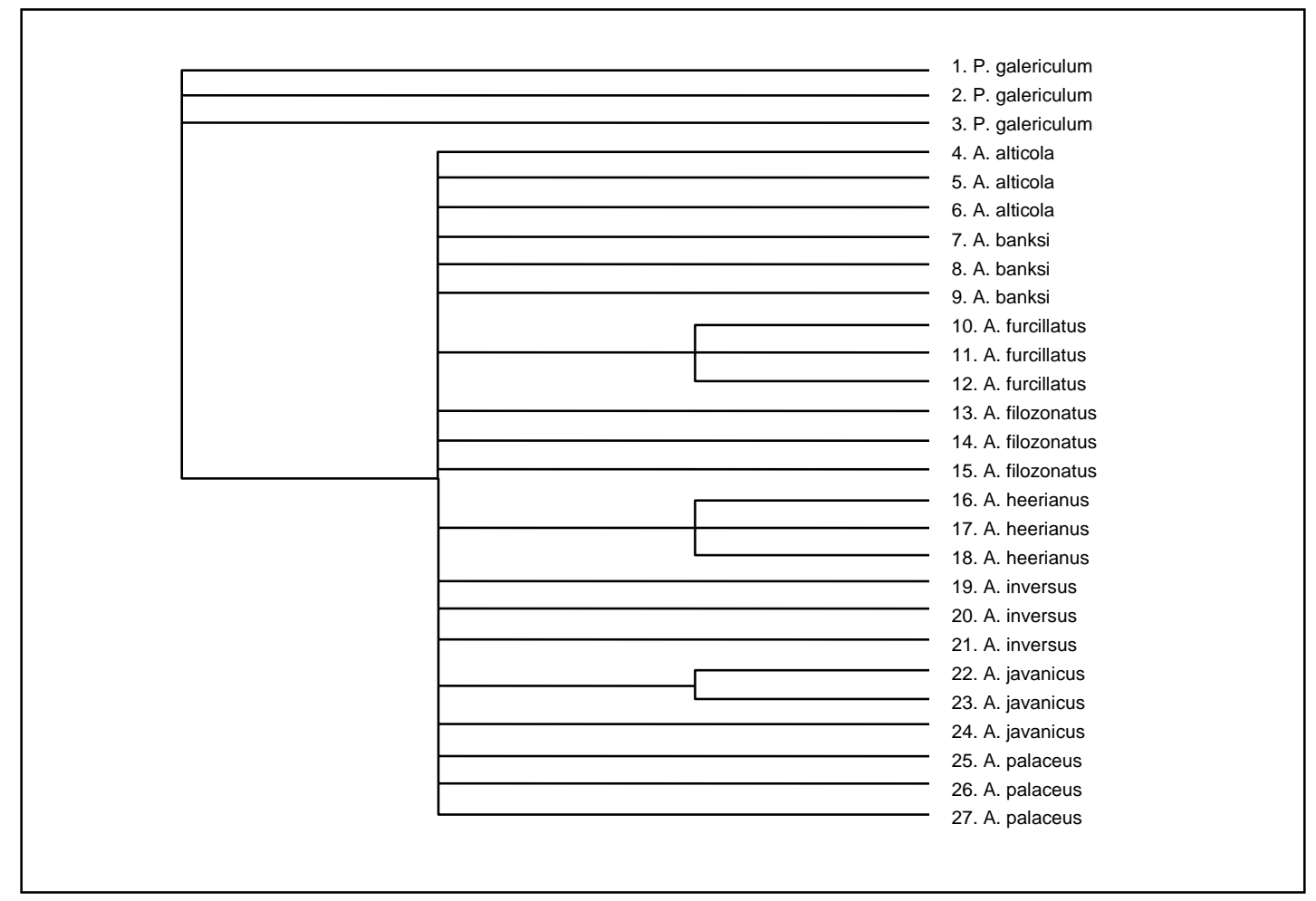

Figure 1. Bootstrap of consensus tree of 27 taxa and 7 characters of Amphidromus on the first trial 


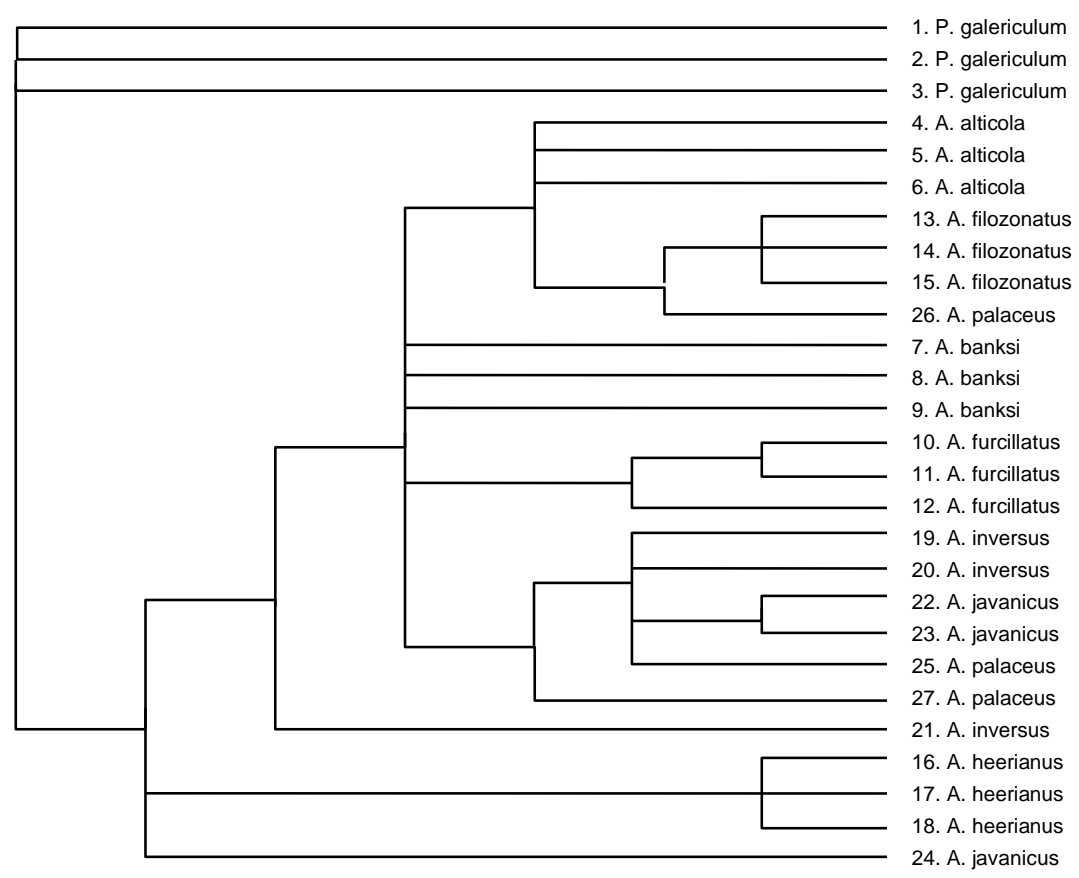

Figure 2. First tree of 27 taxa and 7 characters of Amphidromus on the first trial

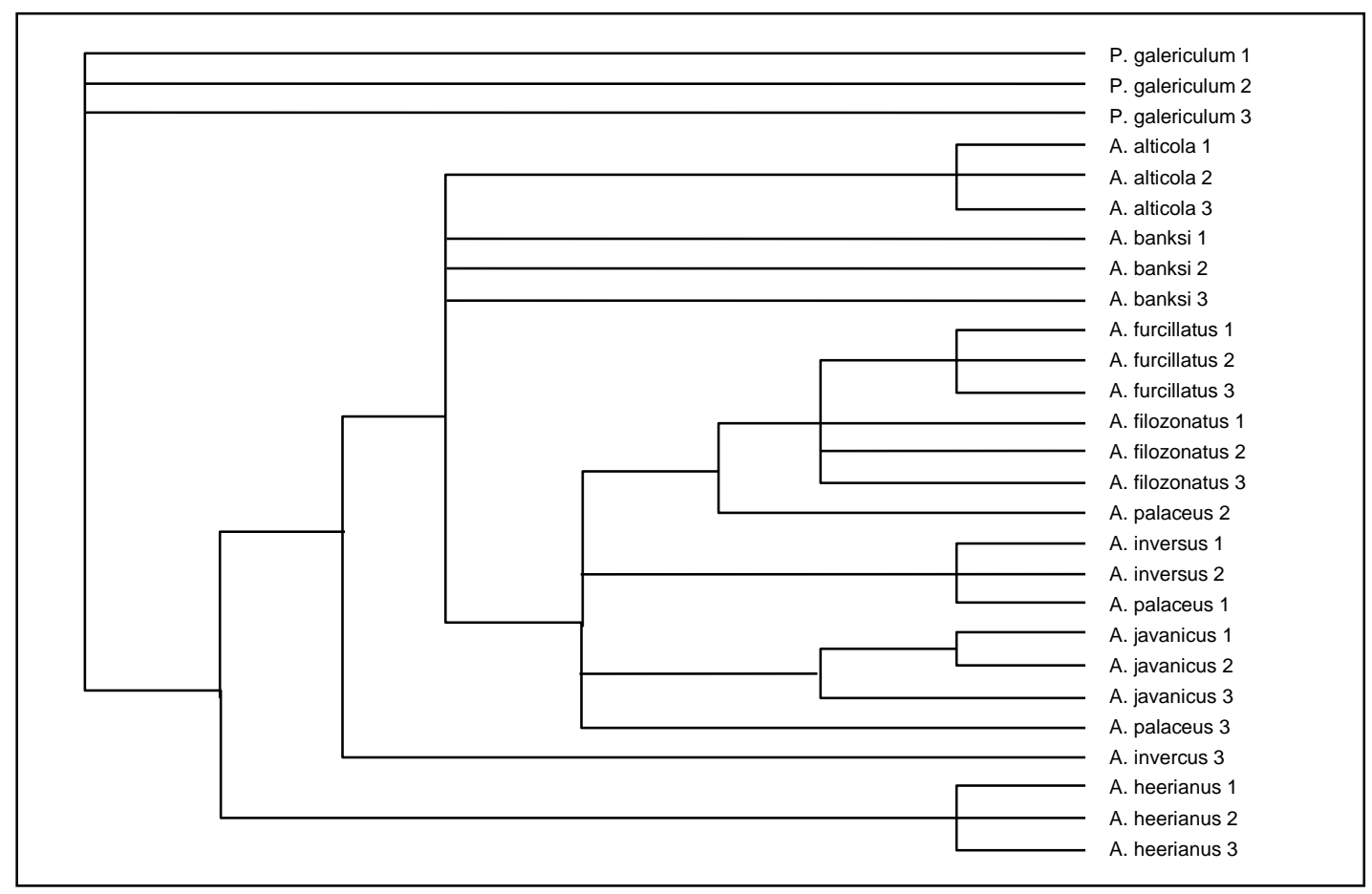

Figure 3. Tree number 1 of Amphidromus on the second trial using 27 taxa and 8 characters 


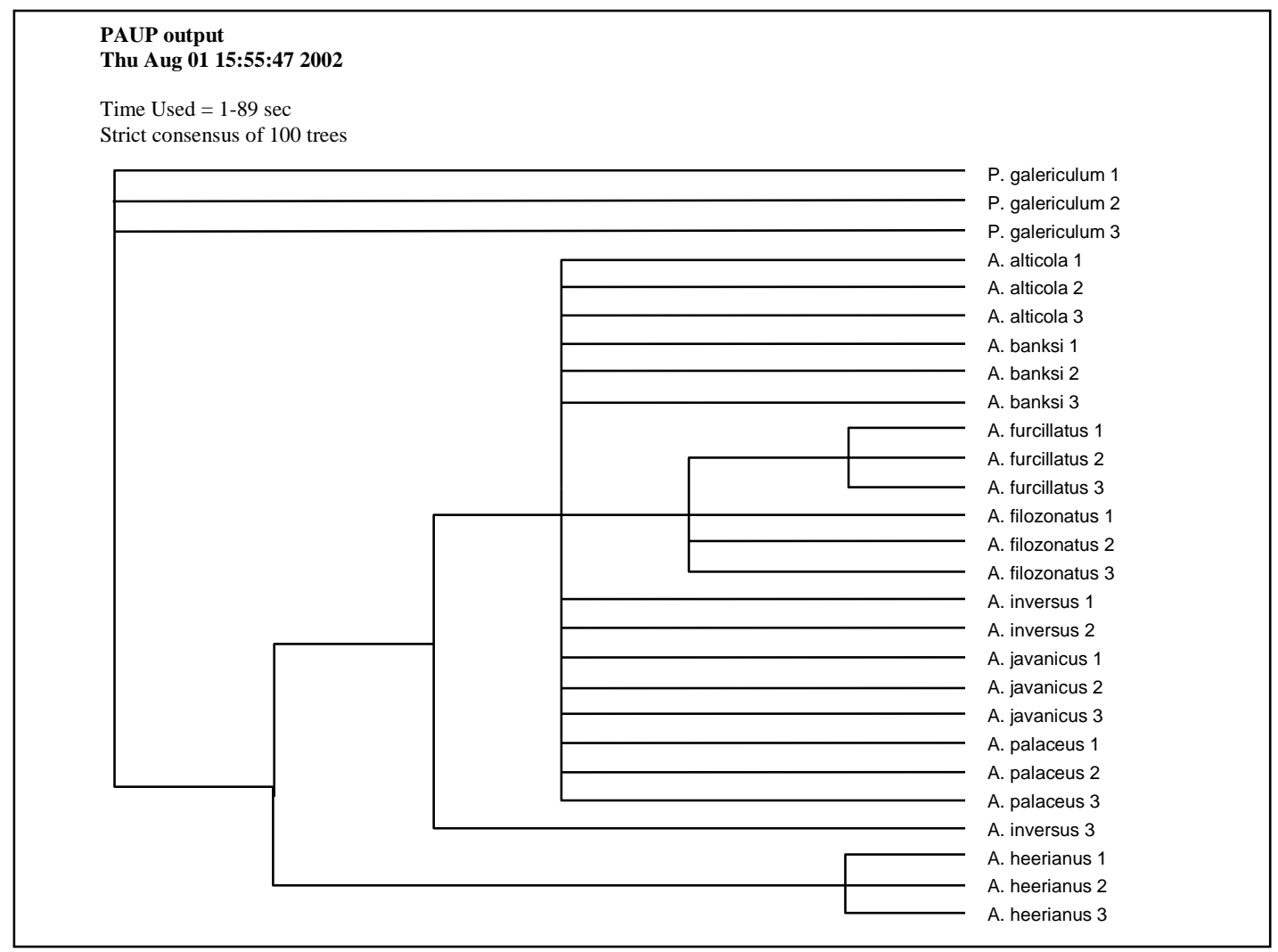

Figure 4. Strict consensus tree of 100 trees of Amphidromus on the second trial using 27 taxa and 8 characters

\section{Acknowledgment}

Thanks to Ristiyanti M. Marwoto, M.Si for her support to use collection of the Museum Zoology Bogor and other facility in this study. Thanks to DR. Louis Deharveng Museum National of Histoire Naturelle de Parisfor his teaching in Cladistic analysis, and his supervising in this study. Thanks to DR. Peter $\mathrm{Ng}$ Raffles Museum of Biodiversity Research/National University of Singapore for his teaching in Cladistic analysis. Thanks to Rosichon Ubaidillah, M.Phil. LIPI for his supervising and advise in data coding and development. Thanks to DR. Edmund Gittenberger National Museum of Natural History Leiden for his lecture on the evolution and Molluscs characters. Thanks to DR. Yayuk R. Suhardjono LIPI who ease the progress report. Thanks to Heriyanto, M.Sc. LIPI for his support and patience during works in the collection room and for the picture taking.
Thanks to Ms. Pratini LIPI for her kindness during the training. Finally thanks to all of participants who help me in many ways.

This study is possible because of the support from ARCBC and European Union in cooperation with Research Center for BiologyLIPI who conducted this training on "Invertebrate Taxonomy with Special Reference to the Less Well-Known Groups".

\section{References}

Jutting, W.S.S. van Benthem. 1950. Systematic Studies on the Non-Marine Mollusca of the Indo-Australian Archipelago. Treubia. 20 (3): 477-497

Kitching, I.J., P.L. Foray, C.J. Humphries, \& D.M. Williams. Cladistics: The Theory and Practice of Parsimony Analysis. $2^{\text {nd }}$ edition. Oxford: Oxford University Press. 
Laidlaw, F.F. \& Alan Solem. 1961. The Land Snail Genus Amphidromus A Synoptic Catalogue. Feldiana: Zooogy. 41(4): 505-677

Schilthuizen, M. 1994. Differentiation and Hybridization in Polytypic Snail. Den Haag: Pasmans offsetdrukkerij B.V.
Vermeulen, J.J. \& A.J. Whitten. 1998. Fauna Malesiana Guide to the Land Snails of Bali. Leiden: Backhuys Publisher.

Zahida, F. 1999. Assessment of Some Characters of Pomacea spp from Luzon, Philippines: Morphometric Study and Radula Presentation. BIOTA IV (2):

Appendix 1. Picture of Amphidromus and Pseudopartula used in Cladistic analysis: (A) Amphidromus alticola, $(B)$ A. banksi, $(C)$ A. furcillatus, $(D)$ A. filozonatus, $(E)$ A. heerianus $(\mathrm{F})$ A. inversus, $(G)$ A. javanicus, $(H)$ A. palaceus and $(I)$ Pseudopartula galericulum (Pictures by Heriyanto)
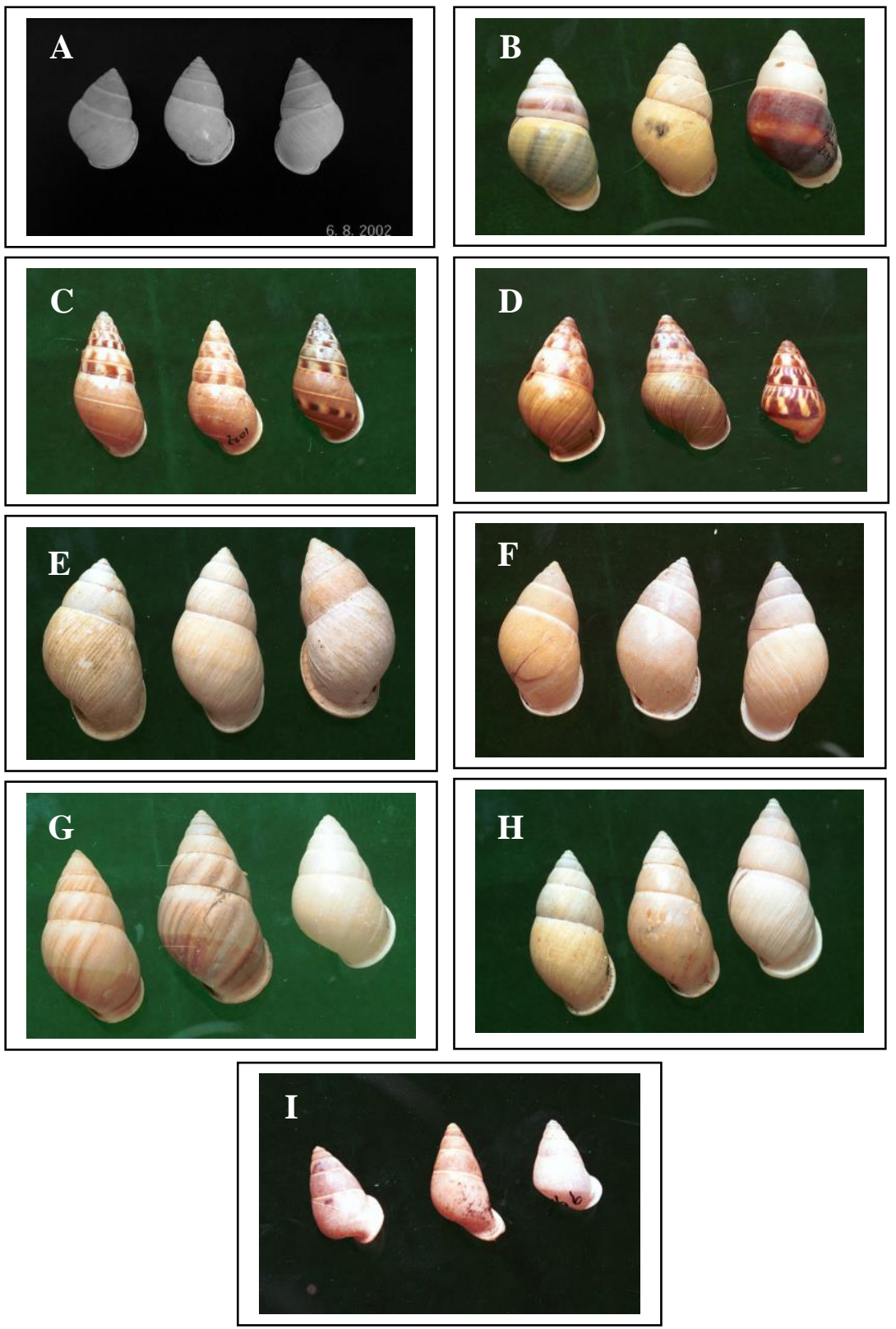
Appendix 2. Amphidromus and Pseudopartula Collection used in Cladistic Analysis

\begin{tabular}{|c|c|c|c|c|}
\hline No & Species & Collector & Locality & Coll. Date \\
\hline 1 & P. galericulum & Ouwens & Sukabumi, West Java & - \\
\hline 2 & P. galericulum & Ouwens & Pamekasan & - \\
\hline 3 & P. galericulum & Ristiyanti/Irvan & Gede Pangrango NP & $18 / 12 / 1996$ \\
\hline 4 & A. alticola & Munandar/Dadang & Cikaniki, GHNP & $11 / 1 / 99$ \\
\hline 5 & A. alticola & Munandar/Dadang & Curug Cikudapeh, GHNP & $14 / 01 / 1999$ \\
\hline 6 & A. alticola & Int.GEF Team & Gede Pangrango NP & $9 / 2 / 00$ \\
\hline 7 & A. banksi & George Hadiprajitno & Lagon Butun & 20/09/1997 \\
\hline 8 & A. banksi & Soetikno & P. Peutjang, West Java & $1 / 3 / 71$ \\
\hline 9 & A. banksi & Ouwens & Jampang & - \\
\hline 10 & A. furcillatus & Olthaff & Jember, East java & 1943 \\
\hline 11 & A. furcillatus & M. Djajasasmita & Blambangan, East Java & 9/10/71 \\
\hline 12 & A. furcillatus & M. Sahlan & Pangandaran, West Java & $8 / 9 / 73$ \\
\hline 13 & A. filozonatus & B. Dharma & Sumenep, Madura & Mar-85 \\
\hline 14 & A. filozonatus & Stein Cullenfels & Ponorogo, East Java & - \\
\hline 15 & A. filozonatus & Lie Goan Liong & Gresik, East Java & $12 / 2 / 61$ \\
\hline 16 & A. heerianus & M. Sahlan & Pangandaran, West Java & $8 / 9 / 73$ \\
\hline 17 & A. heerianus & Machfuds/F. Sabar & Cipatujah, West Java & $10 / 12 / 77$ \\
\hline 18 & A. heerianus & Sutikno & S. Cilegon, West Java & $14 / 1 / 1975$ \\
\hline 19 & A. inversus & AMR Wegner & P. Sebesi, West java & $17 / 6 / 1955$ \\
\hline 20 & A. inversus & Krakatau Exp & P. Krakatau, West java & 1984 \\
\hline 21 & A. inversus & Boen S.O & P. Bintang, West java & $17 / 8 / 1992$ \\
\hline 22 & A. javanicus & Damerman & Depok, West Java & $8 / 8 / 20$ \\
\hline 23 & A. javanicus & Hazzan D & Citaren, West Java & $2 / 7 / 85$ \\
\hline 24 & A. javanicus & B. Dharma & Malimping, Banten & Nov-85 \\
\hline 25 & A. palaceus & A. Munandar & Sukawayana & $6 / 4 / 74$ \\
\hline 26 & A. palaceus & Asman & Tjibodas NP & $11 / 5 / 64$ \\
\hline 27 & A. palaceus & AJ. Whitten & Pameungpeuk, West Java & Nov-92 \\
\hline
\end{tabular}

